Vol. 6, No. 1, 2020

Yurii Filipchuk ${ }^{1}$, Roman Kubai ${ }^{2}$

\title{
DESIGN RESULTS OF CULTURAL AND EDUCATIONAL, THEATRICAL AND ENTERTAINMENT BUILDINGS
}

\author{
${ }^{1}$ Postgraduate student of the Department of architectural environmental design \\ Lviv Polytechnic National University, Lviv \\ e-mail: Yurii.V.Filipchuk@lpnu.ua \\ orcid: 0000-0001-5405-6817 \\ ${ }^{2}$ Senior lecturer Department of architectural environment design \\ Lviv Polytechnic National University, Lviv \\ e-mail: Roman.M.Kubai@lpnu.ua \\ orcid: 0000-0002-2661-0347
}

Received: 09.04.2020 / Revised: 11.06.2020 / Accepted: 18.06.2020

(C) Filipchuk Yu., Kubai R., 2020

https://doi.org/10.23939/as2020.01.143

\begin{abstract}
The article highlights the results of educational, search and competitive design of cultural and educational, theatrical and entertainment buildings, designed by teachers and students of the Department of architectural environmental design, Institute of Architecture, National University of Lviv Polytechnic. Nowadays, the theater architectural industry in Ukraine that specializes in youth audiences and students has no clear answer to the question of what the architecture of contemporary theater for children and young people should be and what functional colors and scenographic palette it should include. The theatrical architecture of buildings for children and youth in modern Ukraine continues to be a copy of the building since the Soviet Union. At the beginning of the 21 st century nothing new appeared except analogs of the Theater of Young Spectators and the Puppet Theater of the former era.

The analysis of more than 25 projects of all ranks has shown that most of them are based not only on the ideas of architects of the second half of the twentieth century but also those that made up a network of cultural and educational, theatrical and spectacular buildings in the former USSR. However, in recent years the projects of the Lviv School of Architecture, and especially after the creation of the Department of Architectural Environmental Design, have changed direction towards finding solutions for the architecture of the future. Evidence of the results of both educational, competitive design and the creation of special courses that reanimate the ideas of the architecture of futurists of the twentieth century - F. Kiesler, I. Leonidov and other architects of futurists in the applied sphere A. Quarmby, K. Tange, B. Fuller and those engaged in the search for architecture, which is at least partially called the architecture of the future - G. Holmin, Wolf D. Prix, G. Krieger.

The materials of the article highlight the main principles of designing cultural and educational, theatrical, and entertainment centers in the 21 st century. The author outlines the factors that continue to harm the future development of cultural and educational, theatrical, and entertainment centers in Ukraine. Highlighted experience of designing search, educational and competition projects on the example of the activity of the Department of architectural environmental design proves that it can find application in the applied architectural and construction industry of the country as a whole.
\end{abstract}

Key words: theater and entertainment centers, cultural and educational centers, theater architecture, design analysis, architecture of the future.

\section{Problem statement}

For today, there are no clear answers to questions in the theater architectural industry in Ukraine that specializes in youth audiences, students, what the architecture of contemporary theater for children and young 
people should be, what functional colors, scenographic palette it should include. The theatrical architecture of buildings for children and young people in modern Ukraine continues to be a copy of the building since the Soviet Union, and at the beginning of the 21st century nothing new appeared except analogs of the Theater of Young Spectators and the Puppet Theater of the former era.

\section{Analysis of recent research and publications}

Since the independence of Ukraine, the ideas of theatrical, entertainmental, and cultural enlightenment architecture have been covered in the writings of Professor V. I. Proskuryakov (Proskuryakov V. I. 2004. c. 584), B. V. Hoy (Proskuryakov V. I., Hoy B. V. 2007. c. 108), R. M. Kubay (Proskuryakov V., Kubay R. 1998. c. 245-252), D. R. Yarema (Proskuryakov V. I., Yarema D. R. 2008. c. 245-249), Z. V. Klymko (Klymko Z. V. 2014. c. 17-34), I. M. Kopulyak (Kopylyak I. M. 2009. c. 160-163), I. V. Humennyk (V. I. Proskuryakov, I. V. Humennyk. 2014. c. 160-166), Yu. V. Filipchuk (Proskuryakov V. I., Filipchuk Yu. V. 2014. p. 168-173) and others.

\section{Objective of the article}

The purpose of the article is to summarize the results of search, educational and experimental projects of cultural and educational, theatrical and entertainment buildings, which will be an example of future design.

\section{Results and discussions}

The research methodology was carried out using the method of empirical research, observation, and comparison of more than 25 projects of cultural, educational and theatrical and spectacular buildings, which were developed with the participation of teachers and students of the Department of architectural environmental design at the Institute of Architecture of the Lviv Polytechnic National University. All considered approbations of architectural ideas in recent years in educational, search, experimental and applied design at Lviv Architecture school can be conditionally grouped in the following directions:

The first is when the design was conducted in a historically formed environment and existing buildings. This should be counted: Design of youth cultural center with development of environment and spaces of universal destination on the street B. Khmelnitsky in Lviv; Forming the architecture of the youth care center. With the development of a pension project on the street Gorodotska, 64 in Lviv (Fig. 1).

Second: projects that were being developed in landscape and urban environments. This is the design of the architecture of the center of creativity and leisure for children based on the closed school named after Andrey Sheptytsky (in the area of Demolition in Lviv); Design of architecture and environment of the cultural and educational center on Chervona Kalyna avenue in Lviv (Fig. 2).

Third: the direction is related to the design of theater and entertainment centers. These include: The design concept of architectural design of the Jewish Colosseum on the street Kulisha in Lviv; Design of architecture and functional and technical organization of the Lysyk House in Lviv (Fig. 3).

Experience in the modern design of cultural and educational, theatrical and entertainment buildings in the premises and spaces of historically formed environment and existing buildings should provide any and contemporary requirements for architecture of this type, such as accessibility, flexibility and transformativeness, multifunctionality, adaptability, reliability and to set the stage for the architecture of the future, to be able to respond to new requests. For example, the design of a youth cultural center designed by the student A. Marinicheva, under the guidance of Yu. Stolyarov, the idea of preserving the historical architectural image of the former factory building in Lviv, which is viewed on the facade on Khmelnitsky Street, was used, along with the idea of dynamics in the architecture of modern forms and spaces that reveal themselves as the courtyard of the designed complex. The author of the project used the idea of alternating the amusement and educational premises with the exhibition spaces of the center, which can change their parameters according to the task. It is worth noting the project of forming the architecture of the youth care center. With the development of a pension project on the street. Horodotskaya, 64 in Lviv, designed by a student of I. Hopta, under the direction of prof. 
V. Proskuryakov and Assoc. S. Ivanov-Kostetsky, where the projected object is in the form of a house-insert in the street line of the historic residential development of the city. This youth care center consists of a complex of buildings, both spatially and functionally, combining residential, educational, medical and educational functions, in the parameters of rooms and areas comfortable for children of all ages. Also, the project of the care center is well integrated into the architectural environment, the use of glass and wood on the facades of the building and multi-level green terraces create a comfortable perception in the anthropomorphic environment.

In the last years of the 21 st century, the concept of designing cultural and educational and theatrical and spectacular buildings in landscape and urban spaces has changed markedly, from the way of synthesis of structures with the existing environment in all its manifestations, but also the desire to compulsory display and take into account the architecture, building the space, organizing the action and designing it as it was in historical prototypes. For example, the project of the architecture of the Center for Creativity and Leisure for Children based on the closed school named after Andrey Sheptytsky (in the area of Znessinia in Lviv) has the concept of a "palace-type" center in the form of hanging gardens, perpetuated by modern stylistic forms and materials. Terracing of the projected levels of the center creates a harmonious construction of space in the landscapes of the park, emphasizes the shape of the existing relief. Another example of design in urban spaces is the project of the cultural and educational center on Chervona Kalyna avenue in Lviv, by O. Pavlosyuk. The design area is located between residential buildings of 70-80 years of the twentieth century, in the largest "sleeping" region of the city. The image of the center building is well suited to the existing environment, because the shape of the building is dynamic, long straight lines are completed with sharp angles, which emphasizes the intensity of the city highway. The functional layout of the building forms a semi-atrium, around which cultural and educational groups of rooms on the one hand, spectacular on the other, which in turn are combined with exhibition spaces and a lobby.

Ideas in the projects of theatrical and entertainment centers have been given new development, for example, the design concept of the architectural solution of the Jewish Colosseum on the street Kulisha in Lviv, by M. Tselenchuk. The idea behind the project is to revive the once-lost theater during the bombing of 1944, which could be the modern Coliseum. The center project was formed from the main hall with a semi-circular arena stage, the shape of which resembled a destroyed theater, also the author proposes the development of the Coliseum with a trend towards the future, with auxiliary entertainment facilities and spaces, and other functional elements such as workshops, interactive spaces and art workshops. Another example of theatrical and entertainment centers project is design of architecture and functional and technical organization of the Lysyk House in Lviv, designed by V. Madyar under the direction of prof. V. Proskuryakov. The projected building contains a spherical space of auditorium and stage, embodying the idea of "boundless theater". The building is named after a famous world-wide stage designer Eugene Lysyk, designed near the building of a painting house at the Lviv Opera House.

\section{Conclusions}

First. The main principles of designing cultural, educational and theatrical and entertainment centers in Ukraine at the beginning of the 21 st century are:

a) Creation of the most diverse functional and spatial conditions for the work of cultural and educational institutions and theater groups.

b) Search, anticipation and formation of non-standard types and forms of cultural services for visitors.

c) The design of cultural, educational and theatrical and entertainment centers must take into account the differences of the historical and cultural context of the territories and regions and be consistent and harmonious with the architectural environment.

Second. Factors that continue to have a negative impact on the development of cultural and educational and theatrical and entertainment centers in Ukraine in the future are:

a) Insufficient financial support from the state for the experimental design of the industry;

b) Absence of experimental-search construction;

c) Small number of institutions conducting complex scientific and methodological, search and applied activities in the field of architecture of cultural, educational and theatrical and spectacular buildings and structures.

Third. Experience in designing cultural, educational and theatrical and entertainment centers, as an example of the activity of the Chair of Architectural Environment Design, Institute of Architecture, Lviv Polytechnic National University proves in its search, training and competition projects that it can be effectively applied in the architectural and construction industries of Ukraine. 


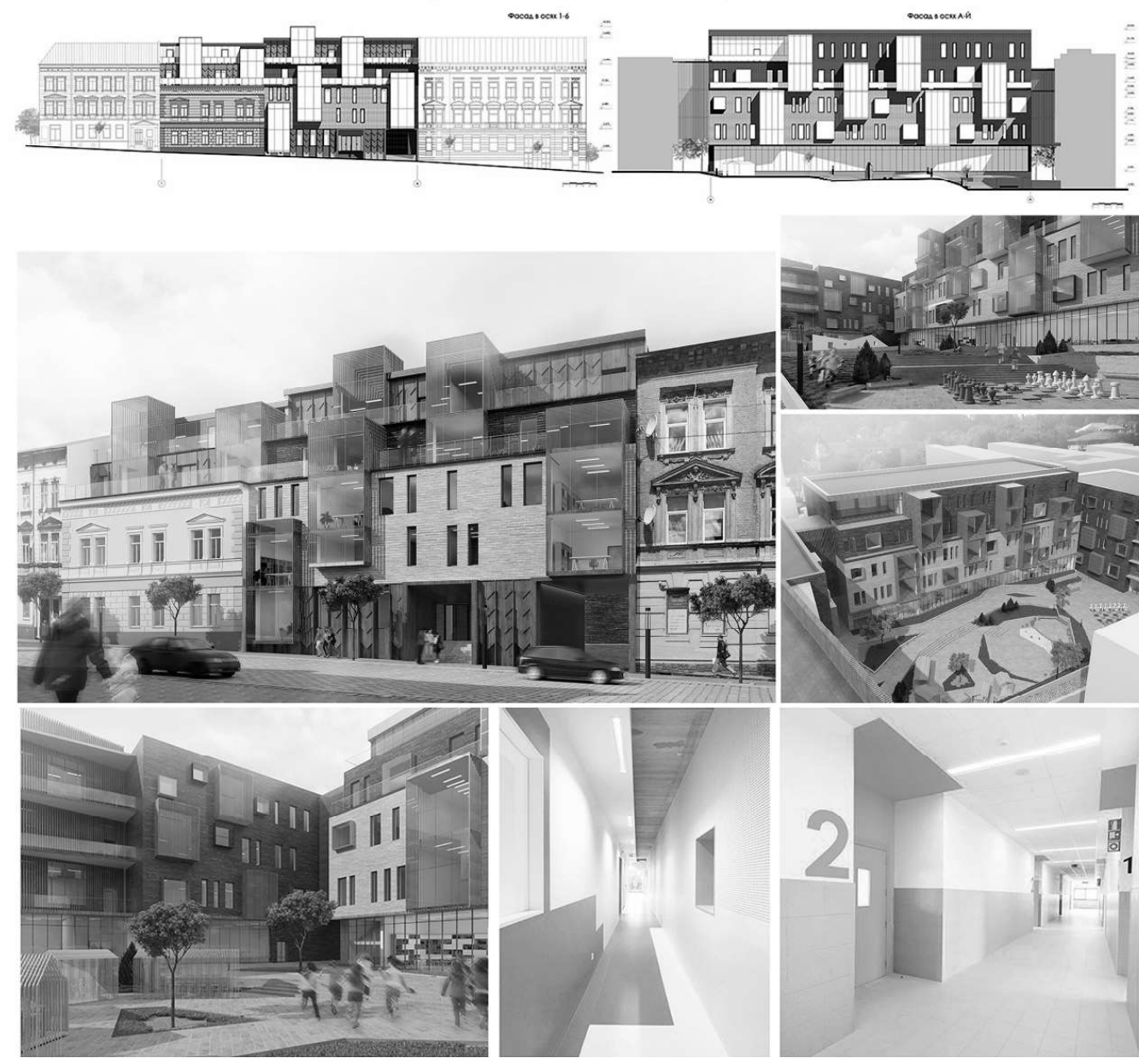

Fig. 1. Forming the architecture of the youth care center. With the development of a pension project on the street Gorodotska, 64 in Lviv.

(from the archive of the Department of architectural environmental design Lviv Polytechnic National University)
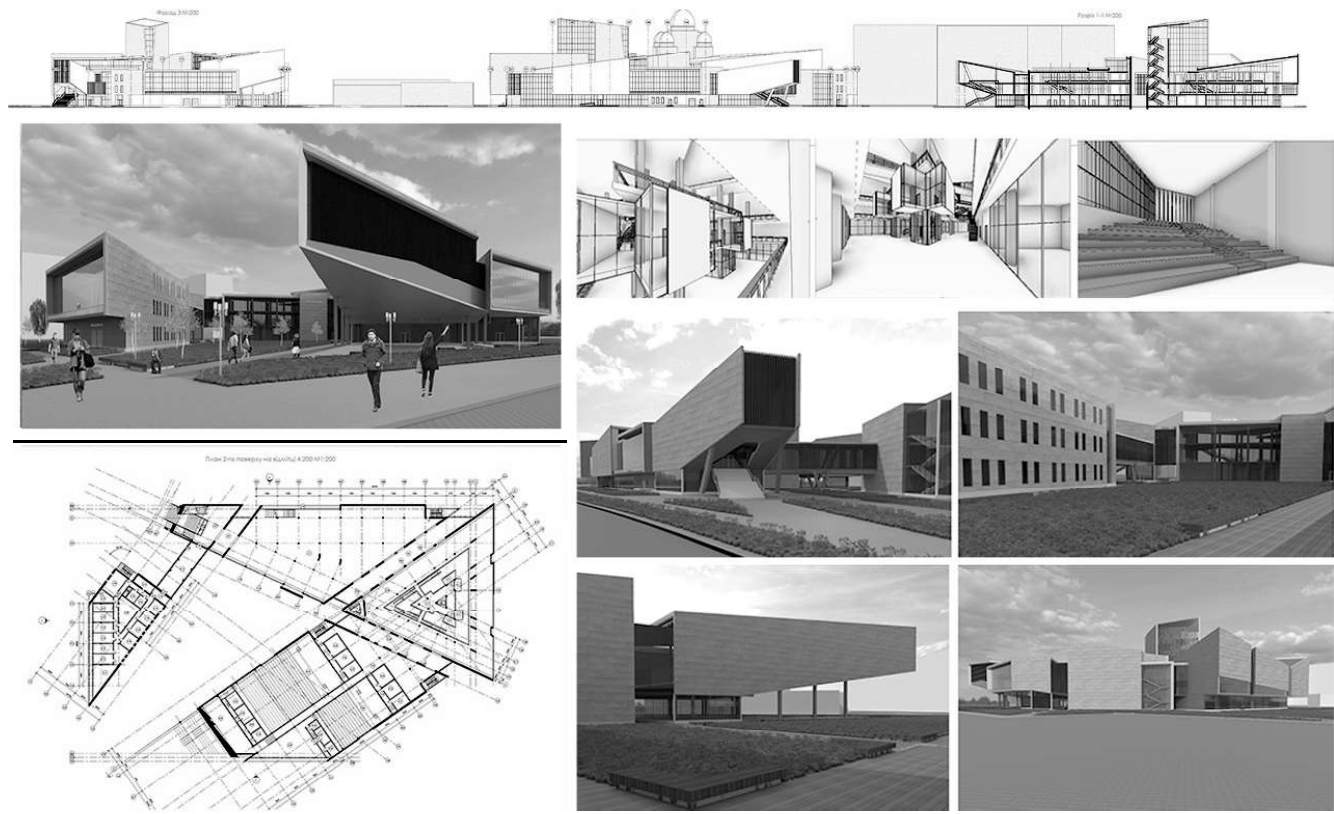

Fig. 2. Design of architecture and environment of the cultural

and educational center on Chervona Kalyna avenue in Lviv (from the archive

of the Department of architectural environmental design Lviv Polytechnic National University) 

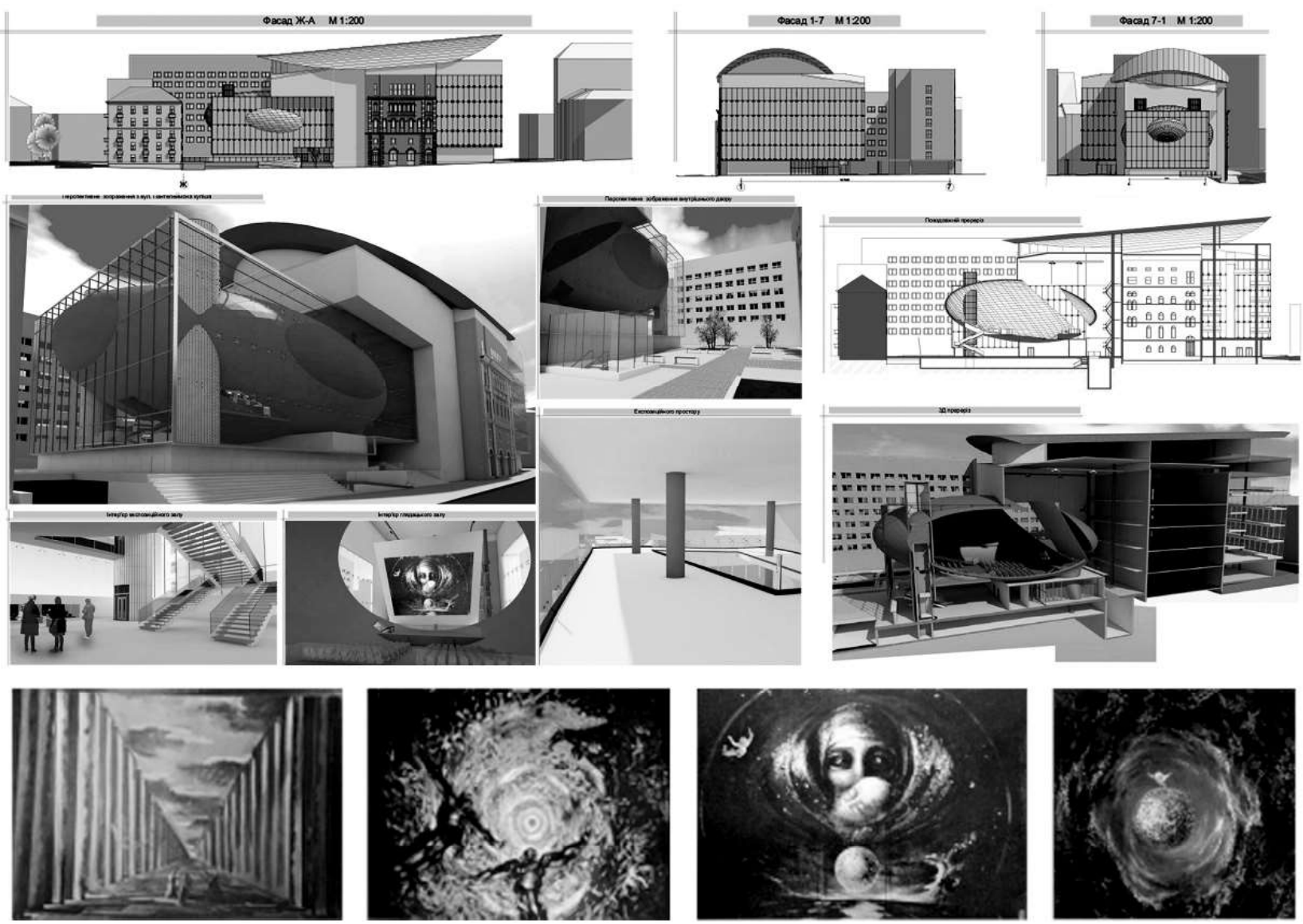

Fig. 3. Design of architecture and functional and technical organization of the Lysyk House in Lviv. (from the archive of the Department of architectural environmental design Lviv Polytechnic National University)

\section{References}

Proskuryakov V. I. 2004. Arkhitektura ukrayinskoho teatru. Prostir i diya: Monohrafiya. Lviv: Vyd.: NU "Lvivska politekhnika"; "Sribne slovo". p. 584.

Proskuryakov V. I., Hoy B. V. 2007. "Kulturolohiya yevreyskoho teatru Ukrayiny v konteksti chasu, diyi i arkhitektury" Lviv: NU Lvivska politekhnika”. p. 108.

Proskuryakov V., Kubay R. 1998. U rusli vidrodzhenykh tradytsiy modernykh kontseptsiy (z dosvidu tvorennya stsenohrafiyi ukrayinskykh, khrystyyanskykh kontsertno-vydovyshchnykh zakhodiv naprykintsi XX st.) / Visnyk "Arkhitektura” NU "Lvivska politekhnika" No. 358. Arkhitektura. p. 245-252.

Proskuryakov V. I., Yarema D. R. 2008. Stsenohrafiya yak holovna skladova arkhitektury teatru. Tradytsiyi ta novatsiyi $u$ vyshchiy arkhitekturno-khudozhniy osviti: Kharkiv: Kharkivska derzhavna akademiya dyzaynu i mystetstv, No. 1, No. 2 , No. 3. p. 245-249.

Klymko Z. V. 2014. Vplyv i rozvytok arkhitekturno - stsenohrafichnykh idey vsesvitno vidomoho stsenohrafa Ye. M. Lysyka Arkhitekturnyy visnyk KNUBA: Vyp. 1. p. 17-34.

Kopylyak I. M. 2009. Teatralni prymishchennya $v$ istorychnykh ukrayinskykh kulturno-prosvitnytskykh budivlyakh (na prykladi Lvova) Visn. Nats. un-tu “Lviv. politekhnika” No. 656. p. 160-163.

Proskuryakov V. I., Humennyk I. V.. 2014. Rezultaty poshukovoho proektuvannya vidkrytykh ta "landshaftnykh" teatriv vykladachamy $i$ studentamy kafedry dyzaynu arkhitekturnoho seredovyshcha Natsionalnoho Universytetu "Lvivska politekhnika". // Visnyk Natsionalnoho universytetu "Lvivska politekhnika", Vyd-vo NU "Lvivska Politekhnika", Arkhitektura. No. 793 [45]. p. $160-166$.

Proskuryakov V. I., Filipchuk Yu. V. 2014. Hipoteza arkhitekturnoho tvorennya teatralno-vydovyshchnykh tsentriv dlya ditey ta molodi na prykladi rozbudovy lyalkovoho teatru u misti Kropyvnytskyy. // Arkhitekturnyy visnyk KNUBA: Vyp. 13. p. $168-173$.

From the archive of the Department of architectural environmental design Lviv Polytechnic National University. 


\author{
Юрій Філіпчук ${ }^{1}$ Роман Кубай ${ }^{2}$ \\ ${ }^{1}$ Аспірант кафедри дизайну архітектурного середовища. \\ Національний університет "Львівська політехніка", Львів \\ e-mail: Yurii.V.Filipchuk@lpnu.ua \\ orcid: 0000-0001-5405-6817 \\ ${ }^{2}$ Старший викладач кафедри дизайну архітектурного середовища. \\ Національний університет "Львівська політехніка", Львів \\ e-mail: Roman.M.Kubai@lpnu.ua \\ orcid: 0000-0002-2661-0347
}

\title{
РЕЗУЛЬТАТИ ПРОСКТУВАННЯ КУЛЬТУРНО-ПРОСВІТНИЦЬКИХ ТА ТЕАТРАЛЬНО-ВИДОВИЩНИХ БУДІВЕЛЬ
}

\begin{abstract}
Анотація. Стаття висвітлює результати навчального, пошукового і конкурсного проєктування культурнопросвітницьких та театрально-видовищних будівель, запроєктованих викладачами та студентами кафедри дизайну архітектурного середовища Інституту архітектури Національного університету “Львівська політехніка". На сьогодні в театральні архітектурні галузі в Україні, яка спеціалізується на молодіжній аудиторії, студентстві, юні немає чітких відповідей на запитання якою повинна бути архітектура сучасного театру для дітей та молоді, які функиіональні забарвлення, сценографічну палітру повинна у собі містити. Театральна архітектура будівель для дітей та молоді в сучасній Украйні продовжуе копію будівлі з часів СРСР, і на початку ХХІ століття не з'явилось нічого нового, окрім аналогів Театру юного глядача та Театру ляльок колишньої доби.

Аналіз більше ніж 25 проєктів усіх рангів засвідчив, що більшість з них спирається не тільки на ідеї архітекторів другої половини ХХ століття, а і ті, що складали мережу культурно-просвітницьких і театрально-видовищних будівель в колишньому СРСР. Але в останні роки діяльність Львівської архітектурної школи і особливо після створення кафедри дизайну архітектурного середовища можна побачити в проєктах і викладачів, і студентів відбувається рух до пошуку рімень архітектури майбутнього. Що засвідчують результати як навчального, конкурсного проектування так $i$ створення спеціальних курсів, що реанімують як ідеї архітектури футуристів ХХ століття - Ф. Кізлера, I. Леонідова $і$ інших архітекторів футуристів прикладній сфері А. Квормбі, К. Танге, Б. Фуллер та і тих щзо займаються пошуками архітектури, яку хоча б частково називати архітектурою майбутнього - Г. Голмін, Вульф Д. Прікс, Г. Крейгер.

У матеріалах статті виокремлені головні принципи проєктування культурно-просвітницьких та театральновидовищних центрів у XXI столітті. Наведено фактори, які й надалі мають негативний вплив на розвиток культурнопросвітницьких та театрально-видовищних иеентрів у майбутньому в Украйні. Висвітлений досвід проєктування пошукових, навчальних та конкурсних проектів на прикладі діяльності кафедри дизайну архітектурного середовища доводить, щуо він може знайти застосування у прикладній архітектурно-будівельній галузі крайни загалом.
\end{abstract}

Ключові слова: театрально-видовищні центри, культурно-просвітницькі центри, театральна архітектура, аналіз проєктування, архітектура майбутнього. 